\title{
Front Matter: Volume 7456
}

, "Front Matter: Volume 7456," Proc. SPIE 7456, Atmospheric and Environmental Remote Sensing Data Processing and Utilization V: Readiness for GEOSS III, 745601 (4 September 2009); doi: 10.1117/12.844707

SPIE Event: SPIE Optical Engineering + Applications, 2009, San Diego, California, United States 


\section{PROCEEDINGS OF SPIE}

\section{Atmospheric and Environmental Remote Sensing Data Processing and Utilization V: Readiness for GEOSS III}

Mitchell D. Goldberg

Hal J. Bloom

Editors

5-6 August 2009

San Diego, California, United States

Sponsored and Published by

SPIE

Volume 7456 
The papers included in this volume were part of the technical conference cited on the cover and title page. Papers were selected and subject to review by the editors and conference program committee. Some conference presentations may not be available for publication. The papers published in these proceedings reflect the work and thoughts of the authors and are published herein as submitted. The publisher is not responsible for the validity of the information or for any outcomes resulting from reliance thereon.

Please use the following format to cite material from this book:

Author(s), "Title of Paper," in Atmospheric and Environmental Remote Sensing Data Processing and Utilization V: Readiness for GEOSS III, edited by Mitchell D. Goldberg, Hal J. Bloom, Proceedings of SPIE Vol. 7456 (SPIE, Bellingham, WA, 2009) Article CID Number.

ISSN 0277-786X

ISBN 9780819477460

Published by

SPIE

P.O. Box 10, Bellingham, Washington 98227-0010 USA

Telephone +1 3606763290 (Pacific Time) · Fax +1 3606471445

SPIE.org

Copyright (C) 2009, Society of Photo-Optical Instrumentation Engineers

Copying of material in this book for internal or personal use, or for the internal or personal use of specific clients, beyond the fair use provisions granted by the U.S. Copyright Law is authorized by SPIE subject to payment of copying fees. The Transactional Reporting Service base fee for this volume is $\$ 18.00$ per article (or portion thereof), which should be paid directly to the Copyright Clearance Center (CCC), 222 Rosewood Drive, Danvers, MA 01923. Payment may also be made electronically through CCC Online at copyright.com. Other copying for republication, resale, advertising or promotion, or any form of systematic or multiple reproduction of any material in this book is prohibited except with permission in writing from the publisher. The CCC fee code is 0277-786X/09/ $\$ 18.00$.

Printed in the United States of America.

Publication of record for individual papers is online in the SPIE Digital Library.

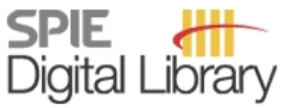

SPIEDigitalLibrary.org

Paper Numbering: Proceedings of SPIE follow an e-First publication model, with papers published first online and then in print and on CD-ROM. Papers are published as they are submitted and meet publication criteria. A unique, consistent, permanent citation identifier (CID) number is assigned to each article at the time of the first publication. Utilization of CIDs allows articles to be fully citable as soon they are published online, and connects the same identifier to all online, print, and electronic versions of the publication. SPIE uses a six-digit CID article numbering system in which:

- The first four digits correspond to the SPIE volume number.

- The last two digits indicate publication order within the volume using a Base 36 numbering system employing both numerals and letters. These two-number sets start with 00, 01, 02, 03, 04, $05,06,07,08,09,0 A, 0 B \ldots 0 Z$, followed by 10-1Z, 20-2Z, etc.

The CID number appears on each page of the manuscript. The complete citation is used on the first page, and an abbreviated version on subsequent pages. Numbers in the index correspond to the last two digits of the six-digit CID number. 


\section{Contents}

vii Conference Committee

\section{SESSION 1 CALIBRATION APPROACHES AND SYSTEMS}

745602 Climate change and sounder radiometric stability [7456-01]

T. S. Pagano, H. H. Aumann, E. Manning, Jet Propulsion Lab. (United States)

745603 Assessment of Midnight Blackbody Calibration Correction (MBCC) using the Global Space-based Inter-Calibration System (GSICS) [7456-02]

M. K. Rama Varma Raja, X. WU, F. YU, L. Wang, NOAA/NESDIS/STAR (United States)

745604 GSICS GEO-LEO intercalibration: baseline algorithm and early results [7456-03]

X. WU, NOAA/NESDIS/STAR (United States); T. Hewison, EUMETSAT(Germany); Y. Tahara, JMA/MSC/SED (Japan)

745605 Using BRDF derived from MODIS observations over Dome $C$ to characterize calibration stability and consistency of POS sensors [7456-04]

A. Wu, Science Systems and Applications, Inc. (United States); X. Xiong, NASA Goddard Space Flight Ctr. (United States); C. Cao, NOAA/NESDIS (United States)

745606 Using the Sonoran Desert test site to monitor the long-term radiometric stability of the Landsat TM/ETM+ and Terra MODIS sensors [7456-05]

A. Angal, Science Systems and Applications, Inc. (United States); X. Xiong, NASA Goddard Space Flight Ctr. (United States); T. Choi, Science Systems and Applications, Inc. (United States); G. Chander, SGT, Inc. (United States); A. Wu, Science Systems and Applications, Inc. (United States)

\section{SESSION 2 DATA UTILIZATION I}

745608 Day-2 product developments for Metop-A [7456-07]

K. D. Klaes, J. Ackermann, R. Munro, A. von Engeln, H. Bonekamp, C. Anderson, P. Schlüssel, T. August, O. Oduleye, J. Schmetz, EUMETSAT (Germany)

7456 OA GSICS GEO-LEO inter-calibration: operation status at NOAA/NESDIS [7456-09]

F. YU, X. WU, Y. Li, G. Rancic, L. Wang, M. K. Rama Varma Raja, NOAA/NESDIS/STAR (United States); S. Sohng, Korean Meteorological Agency (Korea, Republic of); F. Weng,

M. Goldberg, NOAA/NESDIS/STAR (United States) 
7456 OB Development of urban surface models for improved aerosol retrieval [7456-11]

M. Oo, M. Jerg, A. J. Picon, E. Hernandez, B. Gross, F. Moshary, S. Ahmed, The City College of New York (United States)

7456 OC Rich client data exploration and research prototyping for NOAA [7456-12]

M. Grossberg, I. Gladkova, The City College of New York (United States); I. Guch, NOAA (United States); P. Alabi, F. Shahriar, G. Bonev, H. Aizenman, The City College of New York (United States)

7456 OD Remote sensing for bridge health monitoring [7456-13]

W. Liu, S.-E. Chen, E. Hauser, The Univ. of North Carolina at Charlotte (United States)

7456 OF A three-measurement model developed for evaluating satellite land surface temperature product [7456-15]

Y. YU, NOAA/NESDIS/STAR (United States); K. Vinnikov, Univ. of Maryland, College Park (United States); M. Chen, H. XU, I.M. Systems Group, Inc. (United States); D. Tarpley, Short and Associates, Inc. (United States)

\section{SESSION 4 DATA UTILIZATION III}

7456 OG Diurnal drift correction in the NESDIS/STAR MSU/AMSU atmospheric temperature climate data record [7456-16]

C.-Z. Zou, W. Wang, NOAA/NESDIS/STAR (United States)

\section{SESSION 5 PREPARATIONS FOR GOES-R}

7456 OM Improved observations of Earth and space weather from GOES-R [7456-26]

S. Kalluri, J. Gurka, R. Race, NOAA/NASA Goddard Space Flight Ctr. (United States)

745600 Development of IDEA product for GOES-R aerosol data [7456-28]

H. Zhang, R. M. Hoff, Univ. of Maryland, Baltimore County (United States); S. Kondragunta, NOAA/NESDIS (United States)

7456 OP GOES-R Algorithm Working Group (AWG) [7456-29]

J. Daniels, M. Goldberg, W. Wolf, L. Zhou, K. Lowe, NOAA/NESDIS/STAR (United States)

\section{SESSION 6 HYPERSPECTRAL DATA UTILIZATION}

7456 OS Two-year comparison of radiances from the Atmospheric Infrared Sounder (AIRS) and the Infrared Atmospheric Sounding Interferometer (IASI) [7456-32]

D. A. Elliott, H. H. Aumann, Jet Propulsion Lab. (United States); L. L. Strow, S. E. Hannon, Univ. of Maryland, Baltimore County (United States) 
7456 OT An anomaly correlation skill score for the evaluation of the performance of hyperspectral infrared sounders [7456-33]

H. H. Aumann, E. Manning, Jet Propulsion Lab. (United States); C. Barnet, NOAA/NESDIS

(United States); E. Maddy, Perot Systems Government Service, Inc. (United States);

W. Blackwell, MIT Lincoln Lab. (United States)

\section{SESSION 7 DATA ASSIMILATION}

7456 OY Study on ENVISAT ASAR data assimilation in rice growth model for yield estimation [7456-38] S. Yang, S. Shen, Nanjing Univ. of Information Science \& Technology (China); B. Li, Jiangsu Academy of Agricultural Sciences (China); B. Tan, Chinese Academy of Forestry (China)

\section{POSTER SESSION}

745611 Features of the short-term position variation of the west Pacific subtropical high during the torrential rain in Yangtze-Huaihe river valley and its possible cause [7456-20]

Z. Guan, B. Yu, L. Wang, J. He, G. Zeng, Nanjing Univ. of Information Science \& Technology (China)

745612 Possible influence of stratospheric circulation on January surface air temperature over China [7456-21]

G. Tan, W. Zhu, G. Zeng, Z. Sun, L. Peng, Nanjing Univ. of Information Science \& Technology (China)

745614 Low frequency oscillations in assimilated global datasets using TRMM rainfall observations [7456-43]

L. Tao, Nanjing Univ. of Information Science \& Technology (China); S. Yang, NOAA/NESDIS (United States); S. Yang, Nanjing Univ. of Information Science \& Technology (China)

745615 Seasonal predictability of the ensemble seasonal prediction by tier-1 and tier-1.5 models [7456-44]

L. Tao, Nanjing Univ. of Information Science \& Technology (China); B. Wang, X. Fu, Univ. of Hawaii (United States); S. Yang, Nanjing Univ. of Information Science \& Technology (China)

Author Index 
Downloaded From: https://www.spiedigitallibrary.org/conference-proceedings-of-spie on 26 Apr 2023

Terms of Use: https://www.spiedigitallibrary.org/terms-of-use 


\title{
Conference Committee
}

\author{
Conference Chairs
}

Mitchell D. Goldberg, National Oceanic and Atmospheric Administration (United States)

Hal J. Bloom, National Oceanic and Atmospheric Administration, GOES-R Program (United States)

Cochairs

Philip E. Ardanuy, Raytheon Intelligence \& Information Systems (United States)

Allen H. Huang, University of Wisconsin, Madison (United States)

Program Track Chair

Allen H.-L. Huang, University of Wisconsin, Madison (United States)

Program Committee

John J. Bates, NOAA/NESDIS National Climatic Data Center (United States)

James J. Butler, NASA Goddard Space Flight Center (United States)

Changyong Cao, National Oceanic and Atmospheric Administration (United States)

Wei Gao, Colorado State University (United States)

Steve Goodman, National Oceanic and Atmospheric Administration (United States)

John F. Le Marshall, Bureau of Meteorology (Australia)

Johannes Schmetz, European Organisation for the Exploitation of Meteorological Satellites (Germany)

William L. Smith, Jr., NASA Langley Research Center (United States)

Karen St. Germain, National Oceanic and Atmospheric Administration (United States)

Xiaolei Zou, Florida State University (United States)

Session Chairs

1 Calibration Approaches and Systems

Hal J. Bloom, National Oceanic and Atmospheric Administration, GOES-R Program (United States) 
Data Utilization I

James J. Gurka, National Oceanic and Atmospheric Administration (United States)

3 Data Utilization II

Hal J. Bloom, National Oceanic and Atmospheric Administration, GOES-R Program (United States)

4 Data Utilization III

Hal J. Bloom, National Oceanic and Atmospheric Administration, GOES-R Program (United States)

5 Preparations for GOES-R

Hal J. Bloom, National Oceanic and Atmospheric Administration, GOES-R Program (United States)

6 Hyperspectral Data Utilization

Hartmut H. Aumann, Jet Propulsion Laboratory (United States)

7 Data Assimilation

Xiaolei Zou, Florida State University (United States) 